\title{
Understanding Diversity of Outcomes in Organisational Training: A Literature-based View
}

\author{
Muhammad Sharafat Waheeda \\ Noraani Mustaphaa \\ Noor UI Hadib \\ a Faculty of Entrepreneurship and Business, Universiti Malaysia Kelantan (UMK), Malaysia \\ ${ }^{b}$ Department of Leadership \& Management Studies, NDU, Islamabad, Pakistan
}

Doi:10.5901/mjss.2017.v8n3p123

\section{Abstract}

Taking into consideration the limitations of recently published studies, the present study explores the diverse outcomes of HR practices (training being one of them). From a literature-based view, it was found that organisational training improves learning capability in employees if psychological association (the value held) persuades them not to leave the organisation. The relationship between training and organisational performance is explained by employees' performance as well as organisational learning. Findings from this study have practical implications for HR managers and training institutions, and theoretical implications for academics. The formation of intangible assets is a key source of sustainable competitive advantage even in environmental volatility.

Keywords: training; organization learning, organization commitment, employees performance, organization performance.

\section{Introduction and Background}

Training as a strategic investment is a key human resource practice in organisations. Its importance is identified by Marquardt et al. (2000), who highlight that employee training plays a strategic role in the financial success of US organisations which are now able to operate in the global economy. According to Breuer and Kampkotter (2013), the importance of training has evolved over time. Stredwick (2005) asserts that HR practices (including training) have become one of the key sources in improving employee performance in organisations. This is in line with Smith and Hayton (1999), who see training as a factor that develops employee performance. From a statistical analysis, Fpofu and Hlatywayo (2015) found that effective training and development programs improve employees' performance in an organisation, which, they believe, leads to enhanced organisational performance. Muhammad (2010) also highlights the importance of training programs in the context of competitive advantage. Overlooking training programs might decrease the lifetime of employees' skills and knowledge, which affects organisational performance negatively. The present study believes that training programs contribute to the rarity and inimitability of human capital through the sharpening of existing skills and opportunities for learning new skills, which in turn lead to organisational performance (resource-based view). Using social learning theory, knowledge-based view, and the resource-based view of the firm, we attempt to conceptualise the diverse aspects of training outcomes that tend to be poorly understood in previous studies.

\subsection{Rationale of the Study}

Given its valuability, rarity, inimitability and non-substitutability, several researchers (e.g., Barney, 1991; Wright et al., 1994; Hatch and Dyer, 2004) identify human capital as the main source of competitive advantage for organisations. Training as a strategic investment in HR is a key source of improving employee performance (Fpofu \& Hlatywayo, 2015; 
Smith \& Hayton, 1999). Findings from MacDuffie and Kochan (1991) reveal that "firms with high level of strategic investment in training and development showed higher amount of productivity compared to firms with low level of such strategic investment". However, the diversity of training outcomes is poorly understood in existing studies. Alfandi (2016), for example, recommends that "employee performance is not only explained by training and development" (383). ÚbedaGarcia et al. (2013) propose that "the relationship between training and employee performance is not only the result of skills but also the value that they hold inside an organisation" (2855). To address these contemporary issues, we conceptualise a moderating mediating model based on three well-known theories. This integrative model is also an expansion of Dhar's (2015) recommendation.

\subsection{Parent Theories}

The parent paradigms of this study come from the resource-based view, knowledge-based view, and social learning theory. Since human capital is the main source of competitive advantage in an organisation, we take into consideration the resource-based view (Barney, 1991). We consider the knowledge-based view since the creation and transfer of knowledge within organisations is key to their success (Grant, 1996a). The relevance of Bandura's social learning theory is that when organisations train their employees, they tend to reciprocate in positive ways, which affects employees as well as organisational performance (as quoted in Nel et al., 2008).

\section{Review of Literature and Hypothesis Development}

\subsection{Training}

Quality manpower is the pivot of every human institution. Even in industrialised nations - where the use of robots, machines, and technology is at an advanced stage - manpower is still essential (Comma, 2008). Training, therefore, is the key to unlocking growth potential and development opportunities of an organisation. This is why organisations seek to train and develop their employees to the (Devi \& Shaik, 2012).

Training becomes essential to organisations for them to achieve and sustain growth and development. Training is necessary to ensure an adequate supply of staff who are mentally, technically, and socially competent and capable of career development into specialist departments or managerial positions. Training needs to be viewed as an integral part of the process of total quality improvement and management. Beardwell and Holden (1993) point out that the importance of training in recent years has been heavily influenced by the intensification of competition and the relative success of organisations where investment in employee development is emphasised.

Training increases the level of individual and organisational competence. It helps to reconcile the gap between what should happen and what is happening - between desired standards and actual levels of work performance. Consistent with literature (Buckley and Capble, 1995) we operationalise training as the "process of enhancing/developing employees' knowledge, skills, expertise, and capabilities so that they become more productive, for the purpose of carrying out organisational activities successfully".

\subsection{Training and Organisational Performance}

Training must match organisational strategy (Lyles et al., 1993; Delery \& Doty, 1996). A positive association between training and organisational performance was found in several studies (e.g., Javidan, 2004; House et al., 2004; Aycan, 2003). According to Heeters (2006), effective training programs are crucial to organisational survival and success in the long term. This is further supported by Naris and Ukpere (2009), who add that effective employee training programs improve employee performance, which in turn improves business performance. A similar association was found by Ahmad and Bakar (2003) in the context of Malaysia. Even though literature identifies a number of factors that affect organisational performance, the contribution of human resources is considered crucial (Bowra et al., 2011). Training improves the overall performance of an organisation (Aguinis and Kraiger, 2009). Aguinis and Kraiger (2009) operationalise organisational performance as profitability, effectiveness, productivity, etc. Organisational performance can be improved through training programs (AL-Damoe et al., 2012). The quality of employee performance is critical to the organisation's financial performance (Alfandi, 2016; Elnaga and Imran, 2013).

$\mathrm{H} 1$ : There is a relationship between training and organisational performance. 


\subsection{Employee Performance}

Sonnentag and Frese (2002) define individual performance as a multidimensional construct measuring individual behaviour relevant to organisational goals. At the very basic level, Borman and Motowidlo (1993) differentiate between task performance and contextual performance. Task performance is the skills and abilities of an employee which directly (in the case of direct labour) and indirectly (in the case of indirect labour) contribute to the organisation's technical core. Contextual performance, on the other hand, contributes to the organisation's psychological environment (Sonnentag and Frese, 2002; Motowidlo and Schmit, 1999; Borman and Motowidlo, 1997).

Since employee performance is a multidimensional construct, we recommend the scale measure used by Alfandi (2016) for its measurement.

\subsection{Training and Employee Performance}

Training is a process by which the confidence level of employees, their knowledge, and skills are built-up towards an established goal. It is evident from literature $(\mathrm{Ng}, 2005)$ that employee training plays a significant role in their performance.

To improve employee performance, Muzaffar et al. (2012) propose the implementation of on-the-job training programs. It is important to have learning-oriented training programs on a continuing basis. Similarly, to improve the quality of work or employee performance, Delgado Ferraz and Gallardo-Vaqueq (2016) suggest that more specific training policies are required.

The relationship between training, job productivity, job satisfaction, and job effectiveness was investigated by Gummuseli and Ergin in their 2002 study. Afandi (2016) categorises the construct of employee performance into three dimensions: the quality of work, quantity of work, and speed of work. He then links training and development with each dimension. From a regression analysis, he finds that speed of work is highly affected by training and development programs. This is followed by quantity and quality of work. A positive and significant relationship between training and employee performance was found by Mahmood (2012) in her PhD research in the context of Pakistan. Jabeen (2011) and Grana and Bababe (2011) also claim that training is the only way through which employee performance is improved.

Therefore, we argue that improvement in knowledge, skills, expertise and capabilities necessarily responds to environmental volatility. We hypothesise that:

$\mathrm{H} 2$ : There is a relationship between training and organisational performance.

\subsection{Employee Performance and Organisational Performance}

The impact of human capital on organisational performance has been recognised by several researchers (e.g., Seidu, 2011; Hatch and Dyer, 2004; Pennings et al., 1998; and Barney, 1991) in the human resource management and strategy literature. Skilful workers are critical to the success of any organisation, as they constitute its main source of innovation (Manu, 2004). Muzaffar et al. (2012) concur that training and development programs create a sense of self-confidence, self-worth, wellbeing and dignity among employees, whereby they view themselves as valuable assets to the organisation, and that this feeling affects organisational performance positively.

The success and failure of an organisation are heavily dependent on the skills, knowledge, and expertise of its employees (Hameed \& Ahmed, 2011). According to Ali and Aroosiya (2010), employee performance is the key factor influencing an organisation's success. According to Wright et al. (1994) and Hatch and Dyer (2004), human capital is the main source of an organisation's competitive advantage, as it possesses the criteria of valuability, rarity, inimitability, and non-substitutability. We thus hypothesise that:

H3: There is a relationship between employee performance and organisational performance.

\subsection{Employee Performance as Mediator}

The mediating effect of employee performance on the relationship between proactive approach towards training and organisational performance is examined by Niazi (2011: 7), who found that it does mediate the relationship between training and organisational performance. Shaheen et al. (2013) also hypothesise the mediating effect of employee performance on the relationship between training and organisational performance. Analysing 197 valid responses from school teachers in Pakistan, they found a positive association between direct and indirect effects. They conclude that employee performance does explain the relationship between training and organisational performance. Tharenou et al. 
(2007) also proposed the mediating role of employee performance on the relationship between training and organisational performance. Training and development are an important means of improving employee productivity, which ultimately influences the success and effectiveness of the organisation (Singh \& Madhumita, 2012). Okanya (2008) states that training and development programs directly affect employee performance, and indirectly affect organisational performance by means of the mediating effect.

HR practices play an important role in developing human capital, which provides a competitive advantage to a business organisation (Barney \& Wright, 1998). In support of this theoretical argument, MacDuffie and Kochan (1991) found that firms with a high level of strategic investment in training and development showed higher productivity compared to firms with lower levels of such strategic investment. We may conclude that human capital is more proximal to competitive advantage, and therefore mediates the relationship between HR practices and organisational performance.

H4: Employee performance mediates the relationship between training and organisational performance.

\subsection{Organisational Learning}

Argyris and Schon (1996) define organisational learning as "the process by which errors are detected and corrected". According to Shrivastava (1983), organisational learning is "the process developing and shaping organisation knowledgebased". Fiol and Llyles (1995) assert that a process by which organisational action is improved through better knowledge and understanding is known as organisational learning. Huber (1991) defines organisational learning as the process by which a potential range of behaviour is changed through information processing. It is an organisation's enhanced ability to acquire, disseminate, and to use knowledge to adapt to a changing external environment (Hoe and McShane, 2010). These definitions make it clear that organisational learning $(\mathrm{OL})$ is a multidimensional construct. According to Tsang (1997), two aspects of organisational learning tend to be repeated in literature. Sampe (2012) summarises that OL has two main dimensions: cognitive, and behavioural.

The cognitive dimension relates to how an organisation acquires new knowledge. This dimension of $\mathrm{OL}$ is also mentioned by Barba-Aragon et al. (2014), Flores et al. (2012), Jyothibabu et al. (2010), Jimenez and Sanz (2006), and Huber (1991). The behavioural dimension of organisational learning relates to how the organisation adjusts to change, referring to its capability to facilitate the process of learning (Tohidi et al., 2012; Hoe and MsShane, 2010).

The present study subscribes to the definition that organisational learning is an organisation's enhanced ability to acquire, disseminate, and use knowledge in order to adapt to changing external and internal environments, with special focus on individual-level learning. This definition views organisational learning as a continuous effort to create, acquire, and integrate knowledge into daily organisational activities in order to maintain organisational competitiveness and performance (Sampe, 2012).

Popadiuk and Choo (2006) and Kim (1993) explain that "individual level-learning is considered to be a prerequisite for organisational learning". Barba-Aragon et al. (2014) define individual-level learning as "a learning process in which individuals generate new insights and knowledge from existing tacit or explicit knowledge".

\subsection{Training and Organisational Learning}

Planned training programs contribute to learning at the individual, group, and organisational levels (Barba-Aragone, 2014). Since organisational learning is an outcome variable, researchers (e.g., Barba-Aragon et al., 2014; Jerez Gomez et al., 2004; Bartel, 1994; McGill and Slocum, 1993) agree that it is the outcome of HR practices, training and development being the most critical of those practices. A number of studies suggest that $\mathrm{OL}$ is the outcome of training programs (e.g., Barba-Aragon, 2014; Cabrera and Cabrera, 2005; Jerez Gomez et al., 2005; Jerez Gomez et al., 2004).

However, Barba-Aragon et al. (2014) found only one research paper (Jerez Gomez et al., 2004) addressing the relationship between training and organisational capability. They conclude that there is a dearth of research on the relationship between training and organisational learning. They maintain organisational learning as a mediator in examining the relationship between training and firm performance.

Given the state of research as outlined above, we theorise that training affects organisational learning; this learning improves employee performance, which in turn affects organisation performance. We introduce the variable of employee performance in the relationship hypothesised by Barba-Aragon et al. (2014): training $\rightarrow$ organisational learning. The relationship between training and organisational performance is not only explained by organisational learning, but also by employee performance (see sub-section...). We thus hypothesise that:

$\mathrm{H} 5$ : There is a relationship between training and organisational learning. 


\subsection{Organisational Learning and Firm Performance}

Organisational learning has been found to be the basis of sustainable competitive advantage (Brockmand and Morgan, 2003; Garvin 1993), a key enhancer of firm performance (Barba-Aragon et al., 2014; Nevis et al., 1995; Dodgson, 1993). Several recent quantitative studies (e. g., Barba-Aragon et al., 2014; Caps and Lna-Aroca, 2012; Rhodes et al., 2008) have found direct as well as indirect positive association between organisational learning and firm performance. We thus develop the following hypotheses:

H6: There is a relationship between organisational learning and organisational performance.

$\mathrm{H7}$ : Organisational learning mediates the relationship between training and development and organisational performance.

\subsection{Organisational Learning and Employee Performance}

Following up on Alfandi's (2016) suggestion that "employee performance is not only explained by training and development" (p. 383), we introduce individual-level learning as a mediator in the relationship between training and employee performance. We propose that training improves organisational learning and that organisational learning improves employee performance.

H8: There is a relationship between organisational learning and employee performance.

H9: Organisational learning mediates the relationship between training and development and employee performance.

\subsection{Organisational Commitment}

Scholars variously conceptualise organisational commitment (e.g., Dhar, 2015; Sani, 2013; Ariani, 2012; Mahmood, 2012; Ahmad and Bakar, 2003; Bartlett, 2001; Brief, 1998; Steers, 1997; Allen and Meyer, 1996; Liou and Nyhan, 1994; Jaros et al., 1993). From the point of view of Allen and Meyer (1996), organisational commitment is "a psychological association between employee and organisation; this association persuades the employee to not leave the organisation". Mowday et al. (1982) explain employee commitment as "the relative strength of an individual's identification with and involvement in a particular organisation or the behaviour that connects employees to the organisation". Organisational commitment is how loyal the employee feels to the organisation (Mueller et al., 1992; Price, 1997). Tanriverdi (2008) asserts that organisational commitment is the degree to which employees socialise in an organisation for the purpose of fulfilling their job responsibilities.

In the present study, organisational commitment is seen through one of its components affective commitment (recently used by Dhar, 2015; developed by Meyer et al., 1993). Affective commitment is an organisation's ability to predict commitment; this has gained considerable attention from researchers (Meyer et al., 2006).

\subsection{Interactive Role of Organisational Commitment}

The acquisition, distribution, and interpretation of knowledge and organisational memory require creative, capable, and highly committed employees (Wang et al., 2011) capable of continuous learning and growth (McNulty et al., 2008). Since employees' individual-level learning is the basis of organisational learning (Crossan, Lane and White, 1995), their passion for learning is crucial to organisational learning. Úbeda-Garcia et al. (2013) suggest that "the association between training and employee performance is not only the result of skills but also the value that they hold inside an organisation" (p. 2855).

Therefore, the higher employees' commitment to learning, the greater is their learning capability. Employees excel in their work when the organisation creates a favourable working environment. The resulting work environment affects their cognitive growth (their psychological association with the organisation), which in turn affects organisational learning.

H10: The relationship between training and organisational learning is at least moderated through organisational commitment (affective commitment).

$\mathrm{H} 11$ : The relationship between training and employee performance is at least moderated through organisational commitment (affective commitment). 
Figure 1: Conceptual Framework

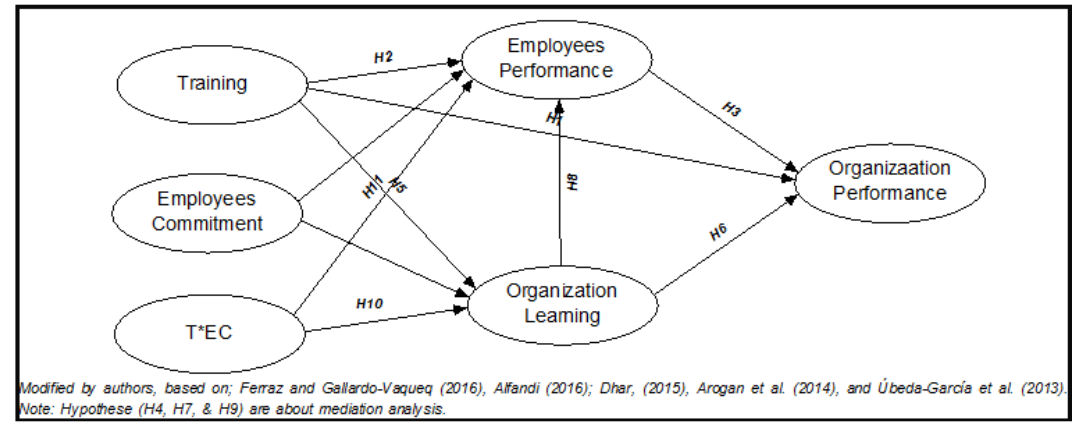

\section{Discussion of Findings}

Training programs are strategically important to the improvement of employees' performance within an organisation. According to Fpofu and Hlatywayo (2015) and Smith and Hayton (1999), training is one of the key sources in improving employee performance. We, therefore, theorise that employee training programs are likely to result in enhanced organisational performance. Also, according to $\mathrm{Ng}$ (2005), "employee training plays a significant role in employee performance". Improvements in existing knowledge, skills, expertise and capabilities positively affect employee performance, which subsequently affects organisational performance.

Barba-Arogan et al. (2014) reveal that training affects learning at the individual, group, and organisational levels, which in turn affects organisational performance. Training affects organising learning; this learning improves employees' performance which affects the organisation's performance. We introduce the variable of employee performance in the relationship hypothesised by Barba-Aragon et al. (2014): training $\rightarrow$ organisational learning. The relationship between training and organisational performance is not only explained by organisational learning, but also by employee performance.

Úbeda-Garcia et al. (2013) also suggest that "the association between training and employee performance is not only the result of skills, but also of the value that employees hold within the organisation". We, therefore, maintain employee commitment as a moderator in the relationship between training and organisational learning, and between training and employee performance. Since there is a high level of correlation between learning and employee performance, we theorise if the psychological association (the value they hold) persuades employees not to leave the organisation, their learning capability and performance depends on training.

\section{Conclusions}

In volatile environments, it is critical for an organisation to maintain sustainable competitive advantage. It has, therefore, become increasingly important to develop new tools able to sharpen existing skills, knowledge, and abilities among employees (Delgado Ferraz \& Gallardo-Vaqueq, 2016). Organisations need to identify ways in which they may be able to sustain competitive advantage. Based on a survey of existing research literature, the present study highlights the importance of different paths (direct and indirect) emanating from training to organisational performance. This is because human capital is the main source of sustainable competitive advantage for an organisation, as they possess the criteria of valuability, rarity, inimitability, and non-substitutability (Barney, 1991).

Our conceptual model offers diverse paths from training outcomes. This understanding is likely to help HR officials manage the crucial direct and indirect paths. For instance, we hypothesise that if the psychological association (the value they hold) persuades employees not to leave the organisation (employee commitment), organisational learning depends on training. This means that in order to improve the learning capability of employees, HR managers must ensure their level of commitment. The study is also likely to enhance academics' understanding of training institutions. From theoretical point of view, this study contributes to organisational learning theory, since there research on how training affects organisational learning and how organisational learning affects employee and organisational performance is scarce. The study also contributes to the resource-based, knowledge-based and cognitive-based views. This is in contrast with prior studies which tend to focus on one or two aspects of training outcomes. The present study focuses on diversity of outcomes by utilising all three theories. 


\subsection{Limitations of Study and Directions for Future Research}

The present study relies on reviewing existing research literature to derive insights. A quantitative study is likely to offer much clearer insight on the crucial path(s) emanating from training to organisational performance. The present study does not consider the cultural aspect of an organisation in hypothesising existing relationships. We recommend that culture be acknowledged and considered in future research on organisational performance.

\section{References}

Aguinis, H. \& Kurt, K. (2009).benefits of training and development for individuals and teams, organizations, and society. Annual Review of Psychology, 60:451-74.

Ahmad, K. Z., \& Bakar, R. A. (2003). The association between training and organizational commitment among white collar workers in Malaysia. International Journal of Training and Development, 7(3), 167-185.

ALDamoe, A. M. F., Yazam, M. Ahmed, B. K. (2012). The mediating effect of hrm outcomes (employee retention) on the relationship between hrm practices and organizational performance. International Journal of Human Resource Studies, 2(1): 2162-3058

Alfandi, A. M. (2016). Training Impact on the Performance of Employees: A Case of Jordanian Travel and Tourism Institutions. International Business Management, 10(4), 377-384.

Allen, N.J.and Meyer, J.P. (1996), 'Affective, Continuance and Normative Commitment To The Organization: An Examination of Construct Validity,' Journal of vocational behavior, 49,252-76.

Ali, H. \&Aroosiya. (2010). Impact of job design on employees' performance (with special reference to school teachers in the kalmunai zone). (Unpublished) BBA (HRM). Thesis, University of Kelaniya, Sri Lanka: 16pp

Argyris, C., Schön, D. A., (1996), Organizational Learning II: Theory, Method and Practice. Reading: Addison-Wesley.

Ariani, D. (2012). Leader-member exchanges as a mediator of the effect of job satisfaction on affective organizational commitment: an empirical test. International Journal of Management, 29(1), 46-56.

Aycan, Z. (2003), 'Human Resource Management in Cultural Context', paper presented at the 7th International Human Resource Management Conference, Limerick, Ireland, June.

Barba Aragon, M. I., Jimnez , D., \& Sanz Valle, R. (2014). Training and performance: The mediating role of organizational learning. BRQ Business Research Quarterly, 17(3), 161-173.

Barney, J. (1991). Firm Resources and Sustained Competitive Advantage. Journal of Management, 17, 1: 99-120.

Beardwell, N. and Holden, B. (1993), Managing for Success, 2nd ed. England: Prentice Hall Publisher.

Borman, W. C., \& Motowidlo, S. J. (1993). Expanding the criterion domain to include elements of contextual performance. In N. Schmitt \& W. Borman (Eds.), Personnel selection in organizations (pp. 71-98). New York: Jossey-Bass.

Borman, W. C., \& Motowidlo, S. J. (1997). Task performance and contextual performance: The meaning for personnel selection research. Human Performance, 10, 99-109.

Bartel, A.P., (1994). Productivity gains from the implementation of employee training programs. Industrial Relations 33, 411-425.

Bartlett, K. R. (2001). The relationship between training and organizational commitment: a study in the health care field. Human Resource Development Quarterly, 12(4), 335-352.

Bowra, Z. A., Sharif, B. \&Niazi, M. K. 2011. Impact of human resource practices on employee perceived performance in banking sector of Pakistan. African Journal of Business Management,6(1): 323-332.

Breuer, K., Kampkotter, P., (2013). Determinants and effects of intra-firm trainings: evidence from a large German company. J. Bus. Econ. 83, 145-169.

Brief, A.P. (1998). Attitudes in an around organizations. Thousan Oaks, CA: Sage.

Brockmand, B., Morgan, F., 2003. The role of existing knowledge in new product innovativeness and performance. Decision Sciences $32,385-419$.

Buckley, R., \& Caple, J. (1995). The theory and practice of training (3rd ed.). London: Kogan Page.

Cabrera, E., Cabrera, A. (2005). Fostering knowledge sharing through people management practices. International Journal of Human Resource Management 16, 720-735.

Camps, J., Luna-Aroca, R., (2012). A matter of learning: how human resources affect organizational performance. British Journal of Management 23, 1-21.

Comma, M. R. (2008), Effect of Manpower Training and Development on Staff Performance and Retention in Federal College of Education, Zaria. Being A Thesis Submitted to the Postgraduate school in Partial Fulfillment of the Requirements for the Award of the Degree of Master of Public Administration (MPA)Unpublished (Online) available at http://kubanni.abu.edu.ng:8080/jspui/bitstream/.

Crossan, M. M., Lane, H. W., White, R. E., \& Djurfeldt, L. (1995). Organizational learning: dimensions for a theory. The International Journal of Organizational Analysis, 3(4): 337-360.

Delery, J.E., and Doty, H.D. (1996), 'Modes of Theorizing in Strategic Human Resource Management: Types of Universalistic, Contingency, and Configurational Performance Predictions,' Academy of Management Journal, 39, 4, 802-835.

Delgado Ferraz, F. A., \& Gallardo-Vázquez, D. (2016). Measurement tool to assess the relationship between corporate social responsibility, training practices and business performance. Journal of Cleaner Production, 129. 659-672. 
Devi, V. R. and Shaik, N. (2012), "Training and Development - A Jump Starter for Employee Performance and Organizational Effectiveness" International Journal of Social Science and Interdisciplinary Research, 1 (7), 2277-3630.

Dhar, R. L. (2015). Service quality and the training of employees: The mediating role of organizational commitment. Tourism Management, 46, 419-430.

Dodgson, M., (1993). Organizational learning: a review of some literatures. Organization Studies 14, 375-394.

Elnaga, A. and A. Imran. (2013). The effect of training on employee performance. Eur. J. Bus. Manage, 5: 137-147.

Fiol, C., \& Lyles, M. (1985). Organizational learning. Academy of Management Review, 10(4): 803-813.

Flores, L.G., Zheng, W., Rau, D., Thomas, C.H., (2012). Organizational learning: sub-process identification, construct validation, and an empirical test of cultural antecedents. Journal of Management 38, 640-667.

Garvin, D.A., (1993). Building a learning organization. Harvard Business Review, 71, 78-91.

Grana, A. B., \& Bababe, F. B. (2011). The effects of motivation on worker performance: A case research of Maiduguri flour mill Itd. Borno State, Nigeria. J. Soc Sci, 4: 8-13.

Grant, R. M. (1996a). "Prospering in Dynamically-competitive Environments: Organizational Capability as Knowledge Integration." Organization Science 7(4): 375-387.

Gumuseli, Ali Ilker and Ergin, Banu. (2002). The Manager's Role in Enhancing the transfer of Training: A Turkish Case Study. International Journal of Training and Development, Vol. 6, pp. 80-97.

Hameed, A.,\&Waheed, A. (2011). Employee Development and Its Affect on Employee Performance A Conceptual Framework. International Journal of Business and Social Science, 2(13):224-229.

Hatch, N. W., \& Dyer, J. H., (2004). Human capital and learning as a source of sustainable competitive advantage. Strategic Management Journal, 25: 1155- 1178.

Heeter, D. (2006). A review of employee training and development. University of Phoenix. Retrieved on July 20,2016 from http://www.oppapers.com/essays/Review-Employee-Training-Development/134768? read essay.

Hoe, S. L., \& McShane, S. (2010). Structural and informal knowledge acquisition and dissemination in organizational Learning An exploratory analysis. The Learning Organization, 17(4): 364-386

House, R.J., Hanges, P.J., Javidan, M., Dorfman, P.W., and Gupta, V. (2004), Culture, Leadership and Organizations, The GLOBE Study of 62 Societies, Thousand Oaks, CA: Sage.

Huber, G. P. (1991). Organizational learning: the contributing processes and the literature. Organization Science, 2(1): 88-116.

Jabeen, M. (2011). Impact of performance appraisal on employees' motivation. Eur. J. Bus. Manage, 3: 197-204.

Jaros , S.T.,Jermier,J.M.,Koehler,J.W.And Sincich,T. (1993) effects of continuance, affective and moral commitment on the withdrawal process: an evaluation of eight structural equation models', Academy of Management Journal 7 (1) : 122:49.

Javidan, M. (2004), 'Performance Orientation,' in Culture, Leadership and Organizations, Organizations, The GLOBE Study of 62 Societies, eds. R.J. House, P.J. Hanges, M.

Javidan, P.W. Dorfman and V. Gupta, Thousand Oaks, CA: Sage, pp. 239-281.

Jerez Gomez, P., Céspedes Lorente, J.J., Valle Cabrera, R., (2004). Training practices and organisational learning capability. Journal of European Industrial Training 28, 234-256.

Jerez Gomez, P., Céspedes Lorente, J.J., Valle Cabrera, R., (2005). Organizational learning capability: a proposal of measurement. Journal of Business Research 58, 715-725.

Jiménez Jiménez, D., Sanz Valle, R., (2006). Innovación, aprendizaje organizativo and resultados empresariales. Un estudio empírico. Cuadernos de Economía and Dirección de la Empresa 29, 31---56.

Jyothibabu, C., Farooq, A., Pradhan, B.B., (2010). An integrated scale for measuring and organizational learning system. Learning Organization 27, 303---327.

Marquardt, M. J., Nissley, N., Ozag, R., \& Taylor, T. L. (2000). Training and development in the United States. International Journal of Training and Development, 4(2), $138-149$.

Kim, D.H., 1993. The link between individual and organizational learning. Sloan Management Review 33, 37-50.

Liou,K.,\& Nyhan,R.(1994). Dimensions of organizational commitment in the Public Sector: Ane

Lyles, M., Baird, I., Orris, B., and Kuratko, D. (1993), 'Formalized Planning in Small Business: Increasing Strategic Choices,' Journal of Small Business Management, 31, 2, 38-48.

MacDuffie, J. P. \& Kochan, T. A., (1991). Does the U.S. under invest in training? Determinants of training in the world economy. Paper presented at the annual meeting of the Academy of Management, Miami

McGill, M.E., Slocum, J.W., (1993). Unlearning the organization. Organizational Dynamics 22, 67-79.

Mahmood, A. (2012). Impact of Training on Commitment, retention and performance. PhD thesis submitted to FUIEMS, Foundation University, Islamabad.

Manu. S. J. (2004). Training and development techniques for improving organizational performance for Ghanaian firms (Unpublished) MS. Thesis, University of Wisconsin-Stout: 48pp

Meyer, J. P., Allen, N. J., \& Smith, C. A. (1993). Commitment to organizations and occupations: extension and test of a three-component conception. Journal of Applied Psychology, 78(4), 538-551.

Meyer, J. P., Becker, T. E., \& Van Dick, R. (2006). Social identities and commitment at work: toward an integrative model. Journal of Organizational Behavior, 27(5), 665-683.

Motowidlo, S. J., \& Schmit, M. J. (1999). Performance assessment in unique jobs. In D. R. Ilgen \& E. D. Pulakos (Eds.), The changing nature of job performance: Implications for staffing, motivation, and development (pp. 56-86). San Francisco, CA: Jossey-Bass. 
Mowday ,R.T.,Porter, L.W.and Steers ,R.M.(1982) , Employee -Organizational Linkages the psychology of Commitment ,Absenteeism, and Turnover (New York : Academic).

Mpofu, M., \& Hlatywayo, C. K. (2015). Training and development as a tool for improving basic service delivery; the case of a selected municipality. Journal of Economics, Finance and Administrative Science, 20(39), 133-136.

Muhammad, A.I. (N/d). Introduction to employee training and development. Retrieved on July 23, 2016 from www.mcgrawhill.ca/olc/noe.

Mueller, C. W., Wallace, J. E., \& Price, J. L. (1992). Employee commitment: Resolving some issues. Work and Occupations, 19, pp. 211-236.

Muzaffar, M. U.,Salamat, S. H. \& Ali, M. M. 2012. Impact of Trainings on Employees Outcome in IT Sector Pakistan. Global Journal of Management and Business Research, 12(6): 20-26.

Naris, S. N., \& Ukpere, W. I. (2009). The effectiveness of an HR code: staff development and training at the Polytechnic of Namibia. Cape Peninsula University of Technology. Business Papers and Reports.

Niazi, A. S. (2011). Training and Development Strategy and Its Role in Organization Performance. Journal of Public Administration and Governance, 1(2), 2161-71104.

$\mathrm{Ng}$, Y. C. (2005). Training determinants and productivity impact of training in China: A case of Shanghai. Econ. Educ. Rev., 24: 275-295.

Nel, P. S., Werner, A., Haasbroek, G. D., Poisat, P., Sono, T., \& Schultz, H. B. (2008). Human Resource Management (7th edition). Southern Africa Oxford University Press.

Nevis, E., Dibella, A., Gould, J., (1995). Understanding organizations as learning systems. Sloan Management Review 36, 73-85.

Okanya, P. S. 2008. Reconciling organizational performance and employee satisfaction through training: the case of soroti district local government. (Unpublished) MA. Thesis, Graduate School of Development Studies: 66pp

Pennings, J. M. Lee, K. \& Van Witteloostuijn A. (1998). Human capital, social capital, and firm dissolution. Academy of Management Journal, 41:425-440.

Popadiuk, S., Choo, S.W., (2006). Innovation and knowledge creation: how are these concepts related? International Journal of Information Management 26, 302-312.

Price, J. L. (1997). Handbook of organizational measurement. Bradford, UK: MCB University Press.

Rhodes, J., Lok, P., Hung, R.Y.Y., Fang, S.C., (2008). An integrative model of organizational learning and social capital on effective knowledge transfer and perceived organizational performance. Journal of Workplace Learning 20, 245-258.

Sampe. F. (2012). The influence of organization learning on performance in Indonesian SMEs. PhD thesis, Southern Cross Univeristy, Lismore, NSW.

Sani, A. (2013). Role of Procedural Justice, organizational commitment and job satisfaction on job performance: the mediating effects of organizational citizenship behavior. International Journal of Business \& Management, 8(15), 57-67.

Seidu, Y. (2011). Human resource management and organizational performance: Evidence from the retail banking sector. Doctor of Philosophy thesis, submitted to Aston University Birmingham.

Shaheen. A., Naqvi. H., \& Khan. M. A. (2013). Employees Training and Organization Performance: Mediation by Employees' Performance. Interdisciplinary Journal of Contemporary Research in Business, 5(4), 490-503.

Shrivastava, P. (1983), "A Typology of Organizational Learning Systems", Journal of Management Studies, Vol. 20, No. 1, pp. 1-28.

Singh, R. \& Mohanty, M. (2012).Impact of Training Practices on Employee Productivity: A Comparative Study. Inter-science Management Review, 2(2): 2231-1513.

Smith, A. and Hayton, G. (1999) .'What drives enterprise training? Evidence from Australia'. The International Journal of Human Resource Management, 10:2,251-272

Sonnentag, S., \& Frese, M. (2002). Performance concepts and performance theory. Psychological Management of Individual Performance, 3-25. John Wiley \& Sons, Ltd. doi: 10.1002/0470013419.ch1

Steers, R.M. (1997), 'Antecedents and outcomes of Organizational commitment ', Administrative Science Quarterly, 22, 46-56.

Stredwick, J. (2005). An introduction to Human Resource Management (2ndedition). Burlington: Butterworth-Heinemann.

Stevens, E., \& Dimitriadis, S. 2004. New service development through the lens of organisational learning: evidence from longitudinal case studies. Journal of Business Research, 57(10): 1074-1084.

Stewart, J. G., McNulty, R., Griffin, M. T. Q., \& Fitzpatrick, J. J. 2008. Psychological empowerment and structural empowerment among nurse practitioners. Journal of the American Academy of Nurse Practitioners, 22: 27-34.

Tanriverdi, H. (2008). Workers' Job Satisfaction and Organizational Commitment: Mediator Variable Relationships of Organizational Commitment Factors. Journal of American Academy of Business, 14(1), pp. 152-163.

Tharenou, P., Saks, A. M., Moore, C. (2007). A review and critique of research on training and organizational level outcomes, Human Resource Management Review, 17: 251-273.

Tohidi, H., Seyedaliakbar, S.M., Mandegari, M., (2012). Organizational learning measurement and the effect on firm innovation. Journal of Enterprise Information Management 25, 219---245.

Tsang, E. W. K. (1997). Organizational learning and the learning organization: a dichotomy between descriptive and prescriptive research. Human Relations, 50(1): 73-89

Úbeda-García, M., Marco-Lajara, B., Sabater, V., Garcia-Lillo, F., (2013). Training policy and organisational performance in the Spanish hotel industry. Int. J. Hum. Resour. Manag. 24 (15), 2851-2875.

Wang, D., Su, Z., \& Yang, D. (2011). Organizational culture and knowledge creation capability. Journal of Knowledge Management, 15(3): 363-373.

Wright P.M. McMahan, G.C. \& McWilliams, A. (1994). Human resources and sustained competitive advantage: A resource-based perspective. International Journal of Human Resource Management, 5, 301-326. 